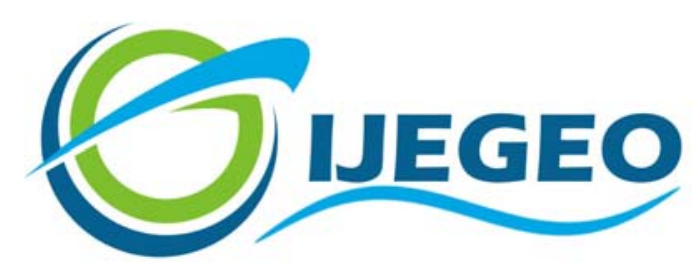

International Journal of Environment and Geoinformatics (IJEGEO) is an international, multidisciplinary, peer reviewed, open access journal.

\title{
Influence of Riverbed Change on a Possibility of Flooding During Water Level Rise of the River Kura
}

\section{Aytaj BADALOVA, Khosiyat ISMATOVA \& Sona GULIYEVA}

\author{
Chief in Editor
}

Prof. Dr. Cem Gazioğlu

\section{Co-Editors}

Prof. Dr. Dursun Zafer Şeker, Prof. Dr. Şinasi Kaya, Prof. Dr. Ayşegül Tanık \& Assist. Prof. Dr. Volkan Demir

Guest Editors

Prof. Dr. Ferruh Yıldız \& Prof. Dr. Ramiz Mahmudoglu Mammadov

\section{Editorial Committee (2019)}

Assos. Prof. Dr. Abdullah Aksu (TR), Prof. Dr. Bedri Alpar (TR), Prof. Dr. Lale Balas (TR), Prof. Dr. Levent Bat (TR), Prof. Dr. Paul Bates (UK), Prof. Dr. Bülent Bayram (TR), Prof. Dr. Luis M. Botana (ES), Prof. Dr. Nuray Çağlar (TR), Prof. Dr. Sukanta Dash (IN), Dr. Soofia T. Elias (UK), Prof. Dr. A. Evren Erginal (TR), Assoc. Prof. Dr. Cüneyt Erenoğlu (TR), Dr. Dieter Fritsch (DE), Assos. Prof. Dr. Çiğdem Göksel (TR), Prof.Dr. Lena Halounova (CZ), Dr. Hakan Kaya (TR), Assoc. Prof. Dr. Maged Marghany (MY), Prof. Dr. Michael Meadows (ZA), Prof. Dr. Nebiye Musaoğlu (TR), Prof. Dr. Erhan Mutlu (TR), Prof. Dr. Masafumi Nakagawa (JP), Prof. Dr. Hasan Özdemir (TR), Prof.Dr. Chryssy Potsiou (GR), Prof. Dr. Erol Sarı (TR), Prof. Dr. Maria Paradiso (IT), Prof. Dr. Petros Patias (GR), Prof. Dr. Elif Sertel (TR), Prof. Dr. Nüket Sivri (TR), Assoc. Prof. Dr. Füsun Balık Şanlı (TR), Prof. Dr. Uğur Şanlı (TR), Assoc. Prof. Dr. Oral Yağcı (US), Prof. Dr. Seyfettin Taş (TR), Assoc. Prof. Dr. Ömer Suat Taşkın (TR), Dr. İnese Varna (LV), Dr. Petra Visser (NL), Prof. Dr. Selma Ünlü (TR), Assoc. Prof. Dr. İ. Noyan Y1lmaz (AU), Prof. Dr. Murat Yakar (TR), Assit. Prof. Dr. Sibel Zeki (TR) 
Dear colleagues and friends,

It is our great pleasure to invite you to attend the EURASIAN GIS Congress 2018 held in Baku on 04-07, September 2018. EURASIAN GIS Congress 2018 is a candidate of one of the most important event in the scientific schedule and tenders a possibility for researchers and academicians who researches on GIS and related disciplines. You can find a first class programme of plenary speakers, technical sessions, exhibitions and social events in this book. You will be able to catch up with the developments in Geographical Information Sciences, Information Technology, Environmental Management and Resources, Sustainable Agriculture, Surveying, Photogrammetry and Remote Sensing, meet friends and experience the traditional and fascinating culture of AZERBAIJAN. As a international congress in the field of geo-spatial information and remote sensing, EURASIAN GIS Congress 2018 is devoted to promote the advancement of knowledge, research, development, education and training in Geographical Information Sciences, Information Technology, Environmental Management and Resources, Sustainable Agriculture, Surveying, Photogrammetry and Remote Sensing, their integration and applications, as to contribute to the well-being of humanity and the sustainability of the environment. The EURASIAN GIS Congress 2018 will provide us an opportunity to examine the challenges facing us, discuss how to support Future Earth with global geo-information, and formulate the future research agenda.

150 scientists from 13 countries attended to the congress. 7 plenary speakers, 120 oral presentations and 8 poster presentations, all together with 135 in total, are presented during the congress. 135 presentations take place in 21 sessions in three days. Badalova et al., (2019) presented in the organization was selected for publication in IJEGEO 6(1) as Short Communication.

The Congress is carried out with the support of the organizations as the Konya Technical University, Selcuk University, Azerbaijan National Academy of Sciences Institute of Geography, Baku State University, Ministry of Agriculture of Azerbaijan Republic, General Directorate of Land Registry and Cadastre, General Directorate of Agricultural Reform of Turkey, International Federation of Surveyors (FIG), International Society for Photogrammetry and Remote Sensing (ISPRS) and Igdir University. In addition, the congress is also supported by the commercial organizations of INTEGRIS LLC, KUTLUBEY Engineering Co, RUBIKON Geosystems LLC, NETCAD, HARMIAD Surveying Engineers Businessmen Association, GEOGIS Engineering Co, MESCIOGLU Engineering Co, EMI Group Information Technology Co, PaksoyTeknik, and 4B Ölçüm.

Finally, we cheer on all of you to participate in this congress of EURASIAN GIS, and special thanks to all sponsorships and government partners for the congress. Enjoy your time and share your experiences with your friends.

Baku/Azerbaijan, September, 2018

Prof. Dr. Ferruh YILDIZ

Chair of The Organizing Committee
Prof. Dr. Ramiz Mahmudoglu MAMMAdoV

Co-Chair of The Organizing Committee 


\title{
Short Communication
}

\section{Influence of Riverbed Change on a Possibility of Flooding During Water Level Rise of the River Kura}

\author{
Aytaj Badalova, Khosiyat Ismatova, Sona Guliyeva* \\ National Aviation Academy, Aerospace Faculty, Department of Aerospace monitoring of the environment, AZ1045, Baku, AZERBAIJAN \\ *Corresponding Author \\ Received \\ 04 Sept 2018 \\ E-mail: guliyeva.s.h@gmail.com) \\ Accepted \\ 10 Apr 2019
}

How to cite: Badalova, et al., (2019). Influence of Riverbed Change on a Possibility of Flooding During Water Level Rise of the River Kura, International Journal of Environment and Geoinformatics (IJEGEO), 6(1): 148-152. DOI: 10.30897/ijegeo.551764

\begin{abstract}
The study of floods by remote sensing data and GIS technology is necessary for the rapid detection of floods in the populated areas, provision of an early evacuation of the population and implementing correct response measures. This paper has been dedicated to studying the methodology of flood mapping by GIS technology on the basis of processing the taken by Earth observation satellite "AZERSKY/SPOT-6" for the period of 2014-2016. Flood-prone areas at river Kura, Khrami and Debed were identified using software package ENVI 5.2 and ArcGIS version 10.4.1. The initial images have been received in the project «Promotion of Earth remote surveillance services for the sake of sustainable development of Azerbaijan» of Azercosmos OJSCo. This research has been carried out on the basis of software and methodological support of «Processing of the aerospace information» sector of «Aerospace Monitoring» within «Aerospace Monitoring of the Environment» department of National Aviation Academy.
\end{abstract}

Keywords: RS, DEM, aerospace monitoring, satellite image, freshet, flood, floodplain, riverbed.

\section{Introduction}

Freshets and floods are natural disasters, covering large territories and exceeding all other emergency situations on damage. The most effective method of tracking them is aerospace monitoring using remote sensing (RS) data of the Earth.

The goal is to identify the zones of flooding in the floodplains of Transboundary Rivers Kura, Khrami and Debed in images taken at different time periods by AZERSKY satellite during the period of summer lowwater and autumn freshet. Using GIS-technologies is necessary to define zones of floodplains of the rivers during the autumn and summer periods, to identify the floodplains of rivers and the nearest territories that are an object to flooding, to calculate their areas, to prepare flood risk maps and create graphs of a cross profile of rivers using DEM model (Farhan et al., 2018; Göksel et al., 2018; Gulivyeva et al., 2017).

\section{Methodology}

Technology for the introduction of aerospace monitoring of freshets and floods

Based on the application of aerospace monitoring of freshets and floods, it is possible:

- $\quad$ to quickly detect areas of flooding;

- $\quad$ to calculate the areas of flood zones;

- to forecast the development of freshets and to assess their potential danger for populated areas and especially important objects;

- $\quad$ to assess and analyse the risks of flooding.
Structural scheme of aerospace monitoring of freshets and floods is shown in fig. 1. It consists of three main blocks: operational mapping, forecasting and verification (Büyüksalih \& Gazioğlu, 2019; Bagheri, 2016; Bódis, 2009; Sopiyak et al., 2004).

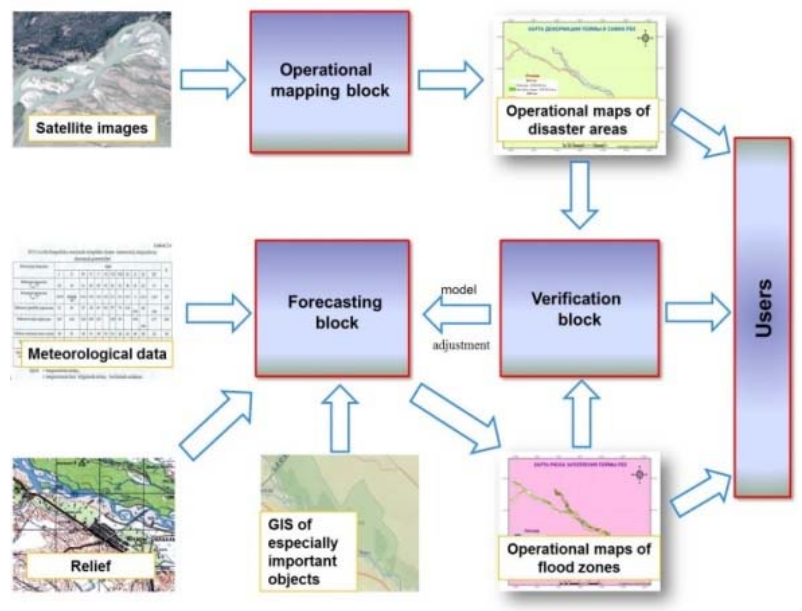

Figure 1. Structural scheme of aerospace monitoring of freshets and floods

Satellite images are sent to the block of operational mapping of flood zones, which uses daily imagery of riverbeds. For monitoring freshets and floods, satellite images of AZERSKY for 2014-2016, data from the Google Earth portal, topographic maps, and data from the ArcGIS Online Internet resource were used. As a result, operational maps of disaster areas are prepared, which are sent either immediately to users, or to the 
verification block, i.e. for ascertaining the veracity of the information obtained. In the verification block, the results of the forecast and operational maps of the flooded areas, constructed on the relevant date, are compared. Based on the results of the comparison, differences are identified, the causes of errors are determined and the model is adjusted. After that, the operational maps are sent to the forecasting block, where it is also necessary to deliver the meteorological data of the studied area, relief data, and data of, especially important objects. The forecasting block serves to forecast the development of the situation in, especially dangerous areas. Calculations for flooding areas in freshets use the calculation functions in ArcGIS. The finished product - operational maps of the flooded areas are sent either repeatedly to the verification block to validate the information, or to users (Kaya \& Tüysüz, 2015; Gulivyeva et al., 2018; Esetlili et al., 2018).

\section{Processing of images taken by AZERSKY satellite}

The floods and freshets prone areas on the river Kura, on the river Khrami flowing into the river Kura, also on the river Debed flowing into the river Khrami were identified by the processing of images for the period 2014 and 2016 using software package ENVI 5.2 and ArcGIS version 10.4.1.

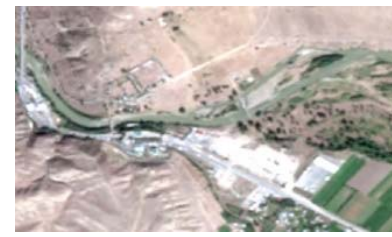

(a)

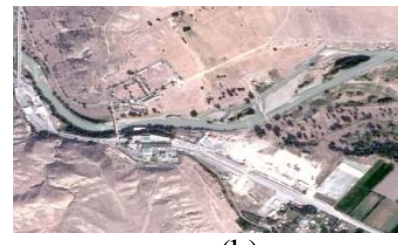

(b)
Figure 2. Images before (a) and after (b) Pan Sharpening

After the visual analysis of the images, it was determined the need to improve the resolution of satellite images, which is carried out during pre-processing. Therefore, in order to improve the visual perception of satellite images with the help of software package ENVI-5.2, we perform the operation Pan Sharpening. Fig. 2 shows images before and after the Pan Sharpening operation.

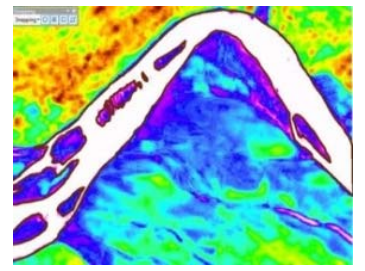

(a)

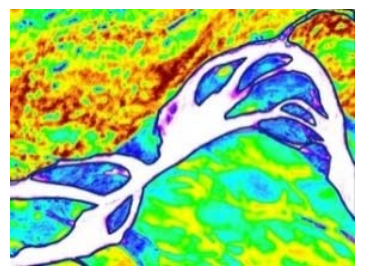

(b)
Figure 3. Fragments of classified images for 2014 (a) and 2016 (b) for the index NDVI

After the successful implementation of the first stage of image processing, we can proceed to the second stage, i.e. to the thematic processing of improved images. For the thematic processing, we use ArcGIS software version 10.4.1.
In order to study the objects under investigation, we use the classification by the NDVI index. Thus, we create index images, which serve as additional material for interpretation. Fig. 3 shows the result of the classification according to the vegetative index NDVI, the land-water boundary is clearly distinguished; riverbanks, forests, etc. are visible.

As a result, flood risk maps of the river floodplains, a map of populated areas exposed to flooding, a map of deformation of the floodplains of rivers Kura and Khrami (Debed) were obtained.

Developed risk maps for 2014, 2016 and a Map of human settlements potentially at risk of flooding, shown in fig. 4-5, are part of a single map database. They are the ultimate cartographic product and have the entire set of hidden attributive information.
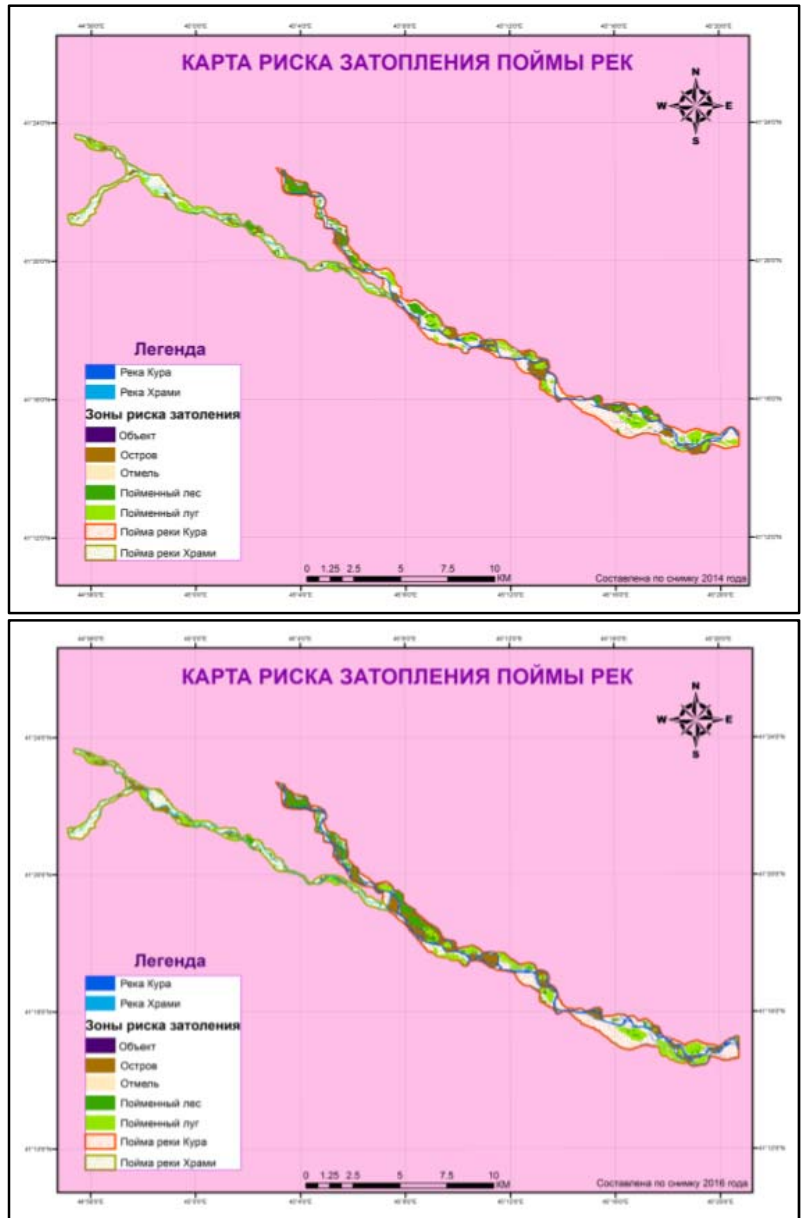

Figure 4. Risk maps of river floodplain flooding, compiled from images of 2014 (a) and 2016 (b)

As a result of calculations using calculate geometry on ArcGIS, it was determined that the village Demirchilar is located at the shortest distance of $40 \mathrm{~m}$ from the river Kura, agricultural field near the village YukharySalakhly by $12 \mathrm{~m}$ and etc. An especially important object located near the floodplain of the river Kura and susceptible to flooding is the nature reserve Gardabani. 


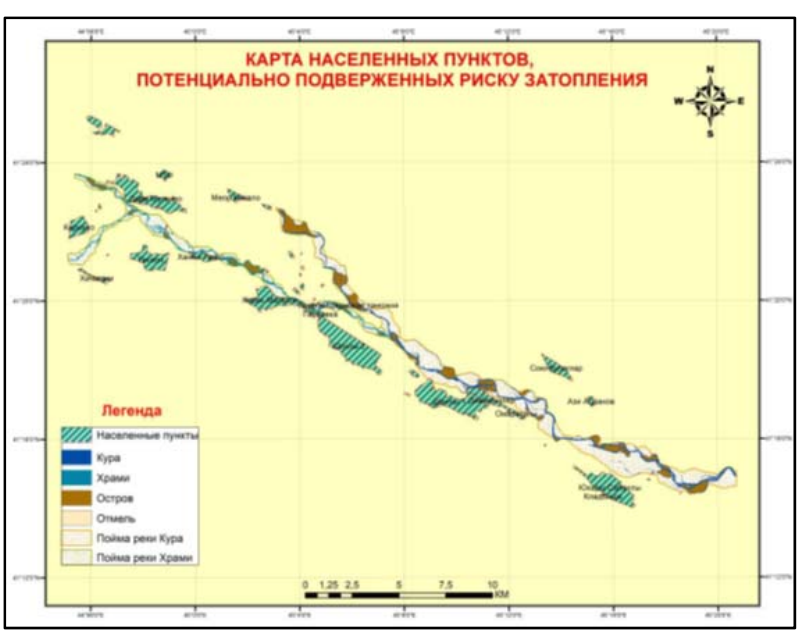

Figure 5. Map of human settlements potentially at risk of flooding

\section{The comparative analysis of the obtained maps}

Having studied separate fragments of the made maps it is possible to see accurately deformation of the riverbed of the river Kura, as shown in figure 6.

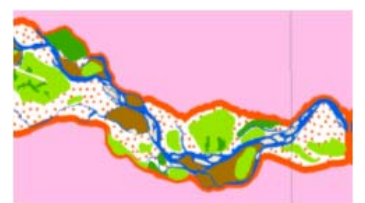

(a)

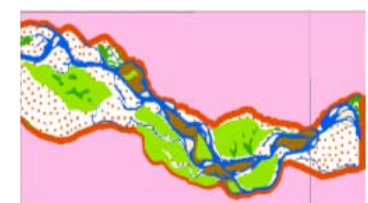

(b)
Figure 6. Fragments of maps for 2014 (a) and 2016 (b) floodplains of the river Kura

During the monitoring period, the obtained maps show the change in the areas and locations of floodplain meadows (on the map they are marked with green color), floodplain islands (brown), floodplain forests (dark green), riverbed (blue) and floodplain (orange).

For the purpose of a more detailed review of the changes, based on the created two risk maps for flooding the floodplains of rivers, a map of the deformation of the floodplains of the rivers Kura and Khrami and the riverbeds of these rivers was created, which is shown in fig. 7.

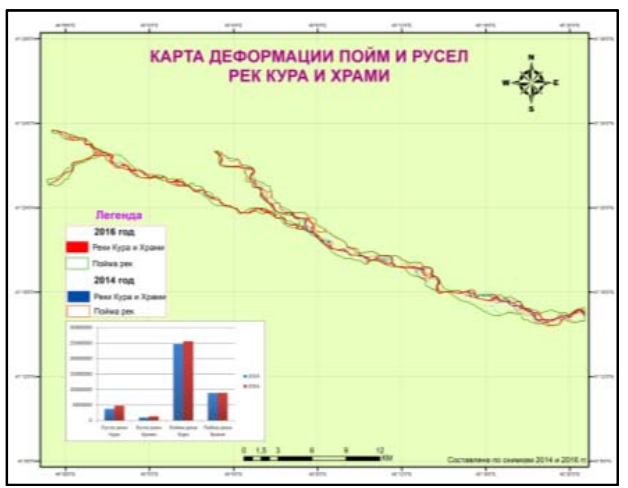

Figure 7. Deformation map of the floodplains and riverbeds of the rivers Kura and Khrami (Debed)
Next, using the statistics function, we can get the smallest, largest area of the object under study and calculate their sum.

Thus, according to the calculations made on ArcGIS and Microsoft Excel, the area of the riverbed of the river Kura increased by $1.05 \mathrm{~km} 2$, and the riverbed of the river Khrami (Debed) - by $0.39 \mathrm{~km} 2$. The floodplain of the Kura increased by $0.91 \mathrm{~km} 2$, and the floodplain of the river Khrami (Debed) increased by $0.012 \mathrm{~km} 2$. The area of the floodplain islands increased by $2.01 \mathrm{~km} 2$, the shoals decreased by $0.48 \mathrm{~km} 2$. The area of forests decreased by $0.022 \mathrm{~km} 2$, and meadows - by $0.23 \mathrm{~km} 2$. The area of objects that were built in the floodplain of rivers increased by $0.0043 \mathrm{~km} 2$ (Gulivyeva et al., 2018).

\section{Creation of the cross profile graphs of the rivers}

In order to confirm the reliability of the information obtained earlier, the research work was carried out on the basis of the DEM model of the study area, which was received from the database of Azercosmos OJSCo.

With a view to determining the possibility of floods in villages that have been shown on a map of human settlements potentially at risk of flooding in fig. 5 , it is important to know the terrain.

The goal was achieved as the application of the DEM model of the study area's relief, on the basis of which it is possible to create the cross profiles graphs of the studied rivers Kura, Khrami and Debed.

First of all, the necessary two DEM models were attached using the Mosaic tool, which is located in the Data Management Tools. When creating a cross profile of rivers on ArcGIS, use the interpolate line tool and profile graph from the $3 \mathrm{D}$ analyst, the lines of the cross profile are drawn a perpendicular to the river's flow from left to right, as shown in fig. 8.
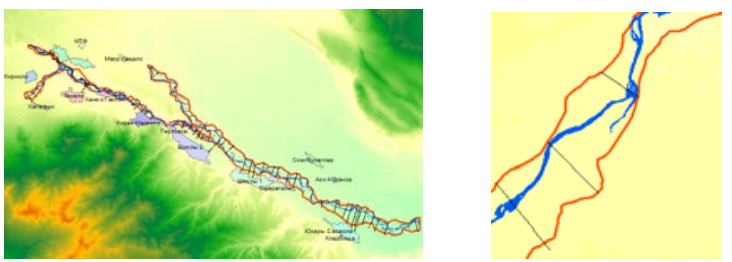

Figure 8. Creation of the cross profile of the rivers Kura, Khrami and Debed

The graph of the cross profile of the river Debed A0-A1 close to the agricultural field, which is located near the village Khachagani, is shown in fig. 9.

According to the curve shown in the graph, the agricultural field is at an altitude of $315.5 \mathrm{~m}$, and if the water level rises by $316 \mathrm{~m}$, there is a risk of flooding and erosion of this agricultural field. The red line indicates the risk of flooding. 


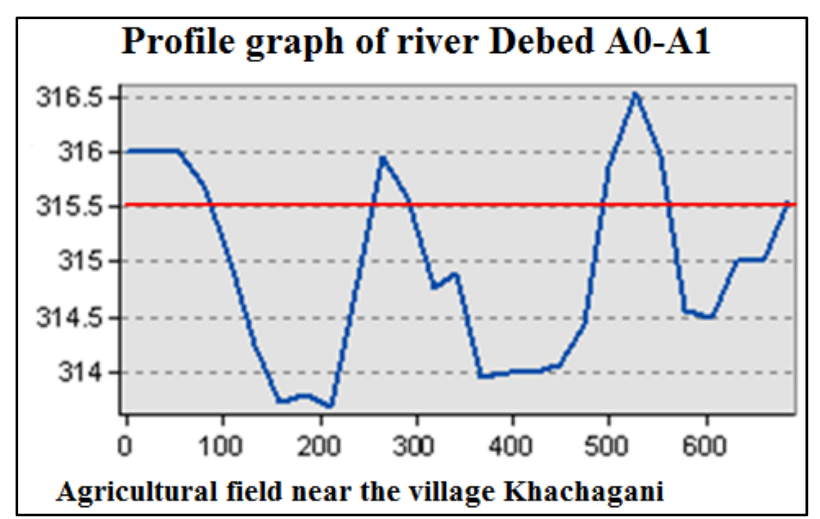

Figure 9. Profile graph of the river Debed A0-A1

The graph of the cross profile of the Khrami River A1A2 near the village of Kirach-Muganlo, which is also located on the territory of Georgia, is shown in fig. 10.

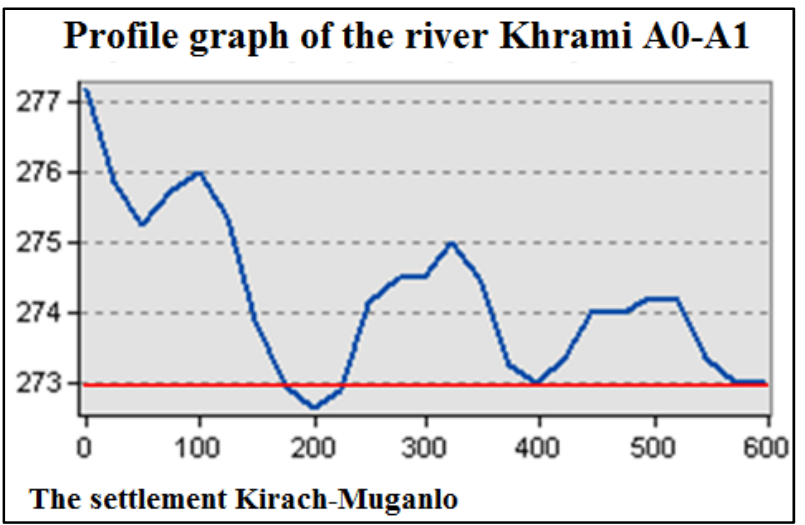

Figure 10. Profile graph of the river Khrami A0-A1

The settlement Kirach-Muganlo is located at an altitude of $273 \mathrm{~m}$ and in case the water level in the river Khrami rises by $1 \mathrm{~m}$, there is a risk of flooding this settlement.

According to the graph presented in fig 11, the agricultural field located near the village Shikhly-2 is located at an altitude of $264 \mathrm{~m}$, and if the water level in the river Kura rises by 2-3 m, it can be assumed that there is a risk of erosion of this field and will thus be destroyed harvest and economic damage.

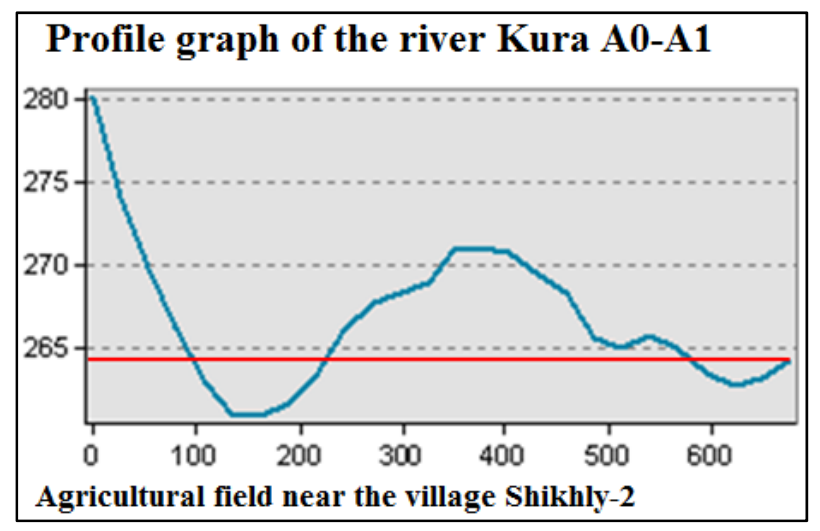

Figure 11. Profile graph of the river Kura A0-A1

The settlement Shikhly-1 is located at an altitude of 251 $\mathrm{m}$ and if the water level of the river Kura rises above this mark shown by the red line in the graph of fig 12 , then the flooding of this village is possible.

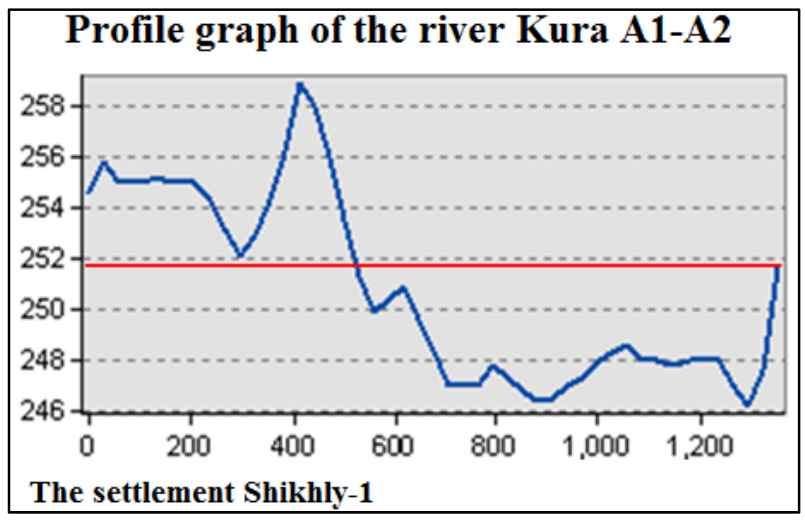

Figure 12. Profile graph of the river Kura A1-A2

The settlement Demirchilar is located at an altitude of $249 \mathrm{~m}$, and if the water level rises above this mark, flooding of this area may occur (fig 13).

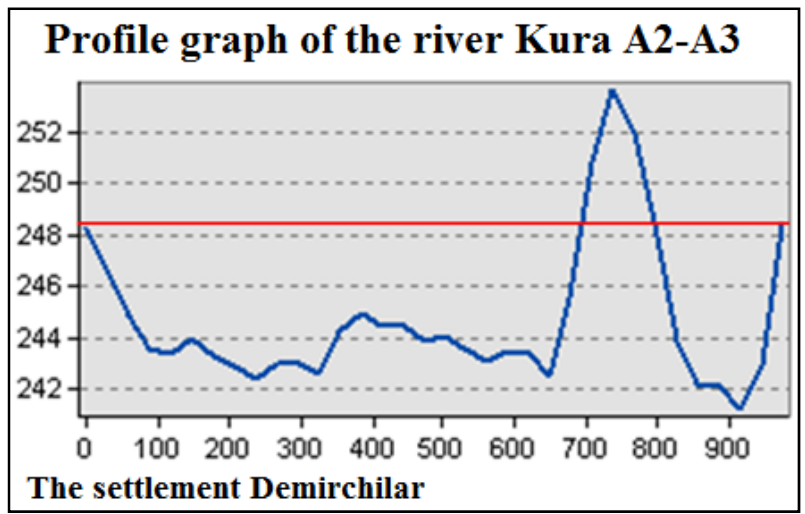

Figure 13. Profile graph of the river Kura A2-A3

\section{Conclusions}

The system of aerospace monitoring of Transboundary Rivers Kura, Khrami and Debed based on the use of GIS-technologies proves the occurrence of flood hazard as a result of the fact that the riverbed is deformed even during the examined 2 years period of 2014-2016.

According to the graphs of cross profiles, which were created based on the DEM model of the study area, the values of river water level rise were assumed, under which there may be a risk of flood hazard on riverbanks. Thanks to the satellite AZERSKY Azercosmos OJSCo., in our country, it was possible to conduct aerospace monitoring of territories with different time periods (for example, annually, according to the season of the year), which allows us to create a database of archival data for use in forecasting and assessing the risk of freshets and floods.

\section{References}

Bagheri, F. (2016). Mapping Drought Hazard Using SPI index And GIS (A Case study: Fars province, Iran), International Journal of Environment and Geoinformatics (IJEGEO), Vol.3(1), 22-28. 
Büyüksalih, İ. \& Gazioğlu, C. (2019). New Approach in Integrated Basin Modelling: Melen Airborne LIDAR, International Journal of Environment and Geoinformatics (IJEGEO), 6 (1), 22-32.

Bódis, K (2009). Development of a data set for hyrdrological modelling. Input layers related to topography, channel geometry, land cover and soil characteristics of European \& African river basins. EC DG-Joint Research Centre, Institute for Environment and Sustainability, 80.

Esetlili, MT., Bektaş Balçık, F., Balık Şanlı, f., Üstüner, M., Kalkan, K., Göksel, Ç., Gazioğlu, C. \& Kurucu, Y. (2018). Comparison of Object and Pixel-Based Classifications For Mapping Crops Using Rapideye Imagery: A Case Study of Menemen Plain, Turkey, International Journal of Environment and Geoinformatics (IJEGEO), Vol. 5(2), 231-243.

Farhan, M., Mozaam, UI. Vansarochana, A. \& Rahman, AU. (2018). Analysis of flood susceptibility and zonation for risk management using frequency ratio model in District Charsadda, Pakistan, International Journal of Environment and Geoinformatics (IJEGEO), Vol. 5(2), 140-153.

Göksel, Ç., David, RM. \& Doğru, AÖ. (2018). Environmental Monitoring of Spatio-Temporal Changes in Northern Istanbul using Remote Sensing and GIS, International Journal of Environment and Geoinformatics (IJEGEO), Vol.5(1), 94-103.

Guliyeva S.H., Badalova A.N. \& Ismatova Kh.R (2017). Application of GIS-technology for flood risk analysis at Kura river, International scientific-technical conference «Natural disasters and human life safety», AUAC, Baku, December 04-06, 2017, 124.

Guliyeva S.H., Badalova A.N. \& Ismatova Kh.R. (2018). Research and prediction of freshets and floods at Kura river by using space images AZERSKY, Materials of III scientifically-practical youth conference with international participation "Creativity of youth in solving aerospace problems", February readings - 2018, NAA, Baku, February 1214, 2018, 114-118.

Kaya, Ş. \& Tüysüz, O. (2015). Using Digital Elevation Model and Remotely Sensed Data in Determining the Geomorphological and Morphometric Features: Gaziköy-Saros Region, Northwestern Turkey, International Journal of Environment and Geoinformatics (IJEGEO), Vol.2(2), 1-15.

Spivak L.F., Arkhipkin O.P., Pankratov V.S., Shagarova L.V. \& Sagatdinova G.N. (2004). Technology of monitoring freshets and flooding in western Kazakhstan, Modernproblems of remote sensing of the Earth from space. Moscow, 2004, 279-285. 